\title{
Magmatic thickening of crust in non-plate tectonic settings initiated the subaerial rise of Earth's first continents 3.3 to 3.2 billion years ago
}

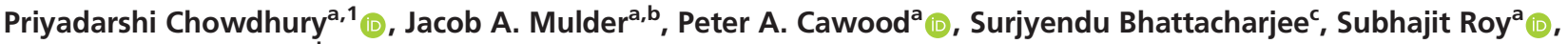 \\ Ashlea N. Wainwright ${ }^{\mathrm{d}_{(}}$, Oliver Nebel $^{\mathrm{a}}{ }_{(}$, and Subham Mukherjee $^{\mathrm{e}}{ }_{(\mathbb{C})}$

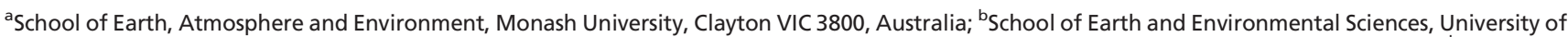 \\ Queensland, St Lucia QLD 4067, Australia; 'Division of Geological \& Planetary Sciences, California Institute of Technology, Pasadena, CA 91125; ${ }^{\mathrm{d} S c h o o l}$ of \\ Geography, Earth and Atmospheric Sciences, The University of Melbourne, Melbourne, VIC 3010, Australia; and 'Department of Geology, University of Delhi, \\ Delhi 110007, India
}

Edited by Roberta L. Rudnick, University of California, Santa Barbara, CA, and approved September 29, 2021 (received for review March 26, 2021)

When and how Earth's earliest continents-the cratons-first emerged above the oceans (i.e., emersion) remain uncertain. Here, we analyze a craton-wide record of Paleo-to-Mesoarchean granitoid magmatism and terrestrial to shallow-marine sedimentation preserved in the Singhbhum Craton (India) and combine the results with isostatic modeling to examine the timing and mechanism of one of the earliest episodes of large-scale continental emersion on Earth. Detrital zircon U-Pb(-Hf) data constrain the timing of terrestrial to shallow-marine sedimentation on the Singhbhum Craton, which resolves the timing of craton-wide emersion. Time-integrated petrogenetic modeling of the granitoids quantifies the progressive changes in the cratonic crustal thickness and composition and the pressure-temperature conditions of granitoid magmatism, which elucidates the underlying mechanism and tectonic setting of emersion. The results show that the entire Singhbhum Craton became subaerial $\sim 3.3$ to 3.2 billion years ago $(\mathrm{Ga})$ due to progressive crustal maturation and thickening driven by voluminous granitoid magmatism within a plateau-like setting. A similar sedimentary-magmatic evolution also accompanied the early (>3 Ga) emersion of other cratons (e.g., Kaapvaal Craton). Therefore, we propose that the emersion of Earth's earliest continents began during the late Paleoarchean to early Mesoarchean and was driven by the isostatic rise of their magmatically thickened $(\sim 50 \mathrm{~km}$ thick), buoyant, silica-rich crust. The inferred plateau-like tectonic settings suggest that subduction collision-driven compressional orogenesis was not essential in driving continental emersion, at least before the Neoarchean. We further surmise that this early emersion of cratons could be responsible for the transient and localized episodes of atmospheric-oceanic oxygenation $\left(\mathrm{O}_{2}\right.$-whiffs) and glaciation on Archean Earth.

continental emersion | crustal thickness | Archean geodynamics tonalite-trondhjemite-granodiorite $\mid \mathrm{O}_{2}$ whiffs and glaciation

$\mathbf{T}^{\mathrm{h}}$ he emergence of continental crust above sea level (called continental emersion) critically influences atmospheric and ocean chemistry, climate, and the supply of nutrients to the oceans via weathering and fluvial runoff $(1,2)$. However, it remains unclear when large areas of subaerial continental crust first appeared on Earth (1-13). A rapid and extensive emersion of continental crust at the Archean-Proterozoic transition (2.5 billion years ago [Ga]) is inferred from abrupt shifts in the oxygen isotope compositions of shales and magmatic zircons, zinc isotope composition of iron formations, and an increase in subaerial continental volcanism at that time $(1,3-5,7)$. However, $>3.0$ to 2.7-Ga-old paleosols (ancient horizons of subaerial weathering) and terrestrial sedimentary rocks that formed atop Earth's earliest stable continental nuclei, the cratons (14-17), provide direct evidence for earlier episodes of continental emersion. This inference is further corroborated by an increase in the diversity of detrital zircon ages in clastic sedimentary rocks from $\sim 2.8 \mathrm{Ga}$ onwards, representing the development of regionally extensive watersheds at that time (13). Thus, subaerial exposure of continental crust before $2.5 \mathrm{Ga}$ seems evident. However, the exact timing and spatial extent of these emersion events are poorly constrained, and their global significance remains unclear. Moreover, the mechanisms and tectonic settings that drove continental emersion during the Archean also remain ambiguous. A uniformitarian view posits that Archean continental emersion (whether at $\sim 2.5 \mathrm{Ga}$ or earlier) was driven by plate tectonics $(1,7,9)$ with subduction-collision processes forming thick continental crust with high-standing topography via magmatism and compressional deformation, as is observed on modern Earth (2). However, the operation of plate tectonics in the Archean is disputed $(9,10,18,19)$, and a growing body of evidence suggests that subduction-collision processes were not globally prevalent until $\sim 2.5$ to $2.0 \mathrm{Ga}$ (10, 20-25), warranting the consideration of alternative mechanisms for producing subaerial continental landmasses on early Earth.

Here, we integrate the Paleoarchean (3.6 to $3.2 \mathrm{Ga}$ ) to Mesoarchean $(3.2$ to $2.8 \mathrm{Ga})$ magmatic and sedimentary records of the Singhbhum Craton of India to elucidate the timing and underlying geodynamics of craton-wide emersion of continental

\section{Significance}

Understanding when and how subaerial continental crust first formed is crucial, as it likely played a critical role in establishing Earth's habitability. Although debated, the broad consensus is that the subaerial rise of continents began $\sim 2.5$ billion years ago and was driven by plate tectonics. Here, we integrate the igneous and sedimentary history of Archean cratons to demonstrate that stable continental landmasses started to emerge above sea level 3.3 to 3.2 billion years ago (i.e., over 700 million years earlier than most models predict). We also demonstrate that these initial episodes of continental emersion were driven by voluminous granitoid magmatism in non-plate tectonic settings that formed $\sim 50-\mathrm{km}$-thick, silica-rich crust, which rose above the oceans due to isostasy.

Author contributions: P.C. and J.A.M. designed research; P.C., J.A.M., S.B., S.R., A.N.W., and S.M. performed research; P.C., J.A.M., P.A.C., and O.N. analyzed data; and P.C., J.A.M., P.A.C., and O.N. wrote the paper.

The authors declare no competing interest.

This article is a PNAS Direct Submission.

Published under the PNAS license.

${ }^{1}$ To whom correspondence may be addressed. Email: priyadarshi.chowdhury@monash. edu.

This article contains supporting information online at http://www.pnas.org/lookup/ suppl/doi:10.1073/pnas.2105746118/-/DCSupplemental.

Published November 8, 2021 
crust in the Archean. This craton is ideal for studying Archean continental emersion as it hosts widespread Mesoarchean terrestrial to shallow-marine siliciclastic strata (26-29) and one of the oldest paleosols on Earth (the 3.29- to 3.08-Ga Keonjhar paleosol) (30) (Fig. 1A), providing an unambiguous record of early subaerial continental crust. We first synthesize detrital zircon data (SI Appendix, Methods and Datasets S1 and S2) from these Mesoarchean strata to determine the timing of emersion of the Singhbhum Craton. Then, we analyze the published compositional data of the craton's Paleo-to-Mesoarchean granitoids (SI Appendix, Methods and Dataset S3) to reconstruct the history of crustal thickening and chemical maturation before and during the emersion. This allows us to link the physicochemical evolution of Archean cratonic crust to its emersion as the long-term topography of subaerial continents is critically controlled by their thick, silica-rich (less-dense) crust, which experiences large positive buoyancy and thereby a greater isostatic uplift relative to the surrounding thin and mafic (more-dense) oceanic crust (2). In particular, we determine the pressure-temperature $(P-T)$ conditions of formation of the tonalite-trondhjemite-granodiorite (TTG) suite of granitoids - the principal crustal component of the Singhbhum Craton. The $P-T$ data provide a time-integrated estimate of crustal thicknesses and elucidate the tectonic process controlling the craton's emersion. These crustal thickness values are cross checked against the independent thickness estimates provided by the La-Yb systematics of the TTGs. Finally, a link between crustal thickening, maturation, and emersion is demonstrated via isostatic modeling.

\section{Ancestry of the Singhbhum Craton}

Located in eastern India, the Singhbhum Craton is comprised of 3.51- to 3.29-Ga greenstone belts (the Iron Ore Group) and a polyphase suite of $\sim 3.36$ - to 3.24-Ga granitoids (the Singhbhum Suite) $(28,29,31)$ (Fig. $1 A$ and SI Appendix, SI Text). Subordinate volumes of Paleoarchean felsic orthogneiss $(\sim 3.53$ to 3.36 $\mathrm{Ga}$; the Champua Suite) and metasupracrustal rocks $(\sim 3.37 \mathrm{Ga})$ together with Mesoarchean $(\sim 3.13$ to $3.08 \mathrm{Ga})$ potassic $(\mathrm{K})$ granites constitute minor components of the cratonic crust. Overall, the craton features a dome-and-keel structure lacking any regional-scale linear tectonic fabric, and the majority of its exposed crust shows low-grade metamorphism without any distinct metamorphic field gradient $(28,29,32)$. The last regionalscale tectonothermal event affecting the cratonic core occurred at $\sim 3.32$ to $3.28 \mathrm{Ga}$ and was characterized by downwelling of the greenstone belt rocks and doming of the granitoid plutons (32, 33). The Mesoarchean siliciclastic strata were deposited atop this cratonic basement $(26,28,29)$. The subsequent evolution of the craton is characterized by the intrusion of $\sim 2.8$-Ga granitoids along the cratonic margin, emplacement of $\sim 2.8-$ to $2.75-\mathrm{Ga}$ mafic dykes, and the development of an accretionary orogenic belt along its southern margin at 2.94 to $2.78 \mathrm{Ga}$, called the Rengali Province $(29,31)$ (Fig. $1 A)$. Thus, the prolonged $(\sim 3.53$
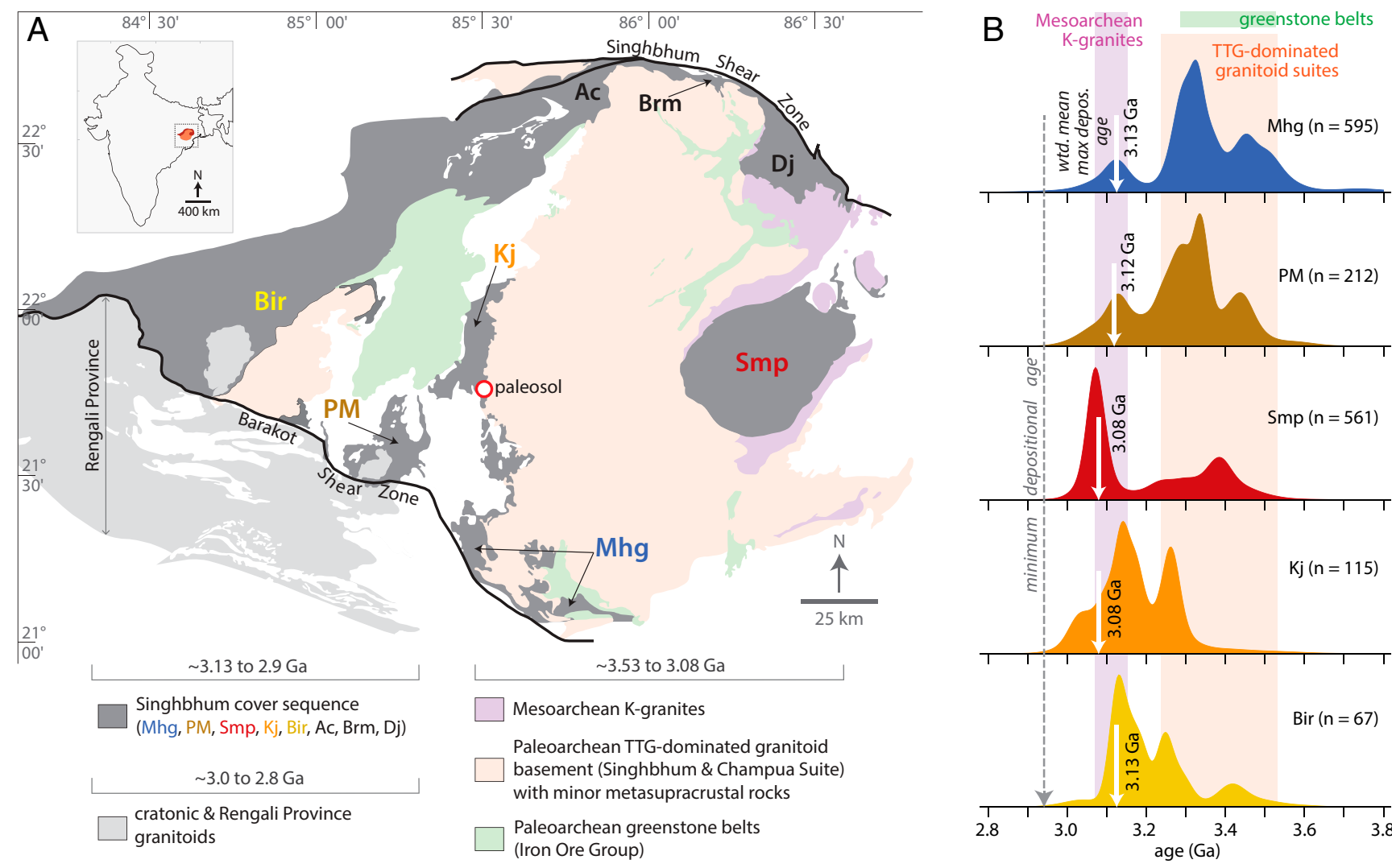

Fig. 1. Spatial distribution and detrital zircon U-Pb ages of the Singhbhum cover sequence. (A) Simplified geological map of the Singhbhum Craton (29, 31) showing the outliers of the Singhbhum cover sequence and their granite-greenstone basement (SI Appendix, SI Text). The orange area in the Inset shows the location of the Singhbhum Craton within the Indian Peninsula. The younger ( 3.0 to $2.8 \mathrm{Ga})$ granitoids (including those of the Rengali Province) that intruded the outliers of the cover sequence are also shown. The formations comprising the outliers include: Mahagiri (Mhg), Pallahara-Mankaharchua (PM), Simlipal (Smp), Keonjhar (Kj), Birtola (Bir), Achu (Ac), Bisrampur (Brm), and Dhanjori (Dj). (B) Kernel density estimate (KDE) of < $\pm 10 \%$ discordant detrital zircon $\left({ }^{207} \mathrm{~Pb} /{ }^{206} \mathrm{~Pb}\right)$ ages from different outliers of the cover sequence (SI Appendix, Fig. S1). For each outlier, the white arrow shows the weighted mean ${ }^{207} \mathrm{~Pb} /{ }^{206} \mathrm{~Pb}$ age of the youngest detrital zircon population, which represents its maximum depositional age (SI Appendix, Fig. S1). The minimum depositional age (dashed gray line) of $\sim 2.94 \mathrm{Ga}$ is constrained from a metamorphic event that affected the outliers. The colored bands show the age brackets of the different phases of granitoid magmatism and greenstone belt formation. Data are in Dataset S1. Refer to SI Appendix, Methods and SI Text for details. 
to $3.1 \mathrm{Ga}$ ) record of granitoid magmatism and lack of younger $(<3.2 \mathrm{Ga})$ tectonism within the cratonic core provide a detailed and pristine record of crustal evolution that allows us to correlate the processes of crustal thickening, maturation, and emersion in a coherent geological and geochronological framework.

\section{The Timing of Continental Emersion}

The Singhbhum Craton is fringed by discrete outliers of $\sim 0.3$ to $1.0-\mathrm{km}$-thick siliciclastic strata that unconformably overlie the granite-greenstone basement (Fig. 1A). The lithostratigraphy of these outliers are strikingly similar (Dataset S4). Each outlier commences with a basal unit of interbedded conglomerate and sandstone deposited in alluvial-fan to (braided-)fluvial systems, which passes conformably upwards into a sequence of fluvial to shallow-marine sandstones (dominantly quartz arenite) preserving ubiquitous trough and planar crossstratification with local herringbone cross-stratification, megaripples, and mud drapes $(26,28,30)$. The sandstones are overlain by fine-grained heterolithic (interbedded sandstoneshale) units and shale, which reflect deeper-water sedimentation $(26,28,30)$. These lithological and stratigraphic similarities support a correlation between these outliers, which are herein collectively referred to as the Singhbhum cover sequence. This correlation is further supported by the similar detrital zircon provenance of each outlier (Fig. $1 B$ and SI Appendix, Figs. S1 and S2). The detrital zircon provenance of the entire cover sequence is characterized by age populations at 3.0 to $3.15 \mathrm{Ga}$, 3.25 to $3.35 \mathrm{Ga}, 3.40$ to $3.50 \mathrm{Ga}$, and rare Eoarchean to Hadean grains (Fig. $1 B$ ). However, the relative proportion of these age populations vary between the outliers (SI Appendix, SI Text and Figs. S1 and S2). The main detrital zircon age populations overlap with the major phases of granitoid magmatism in the craton (Fig. 1B). Additionally, the supra- to subchondritic Hf compositions $\left(\varepsilon \mathrm{Hf}_{(\mathrm{i})}=-5\right.$ to +5$)$ of these detrital zircons are similar to the compositions of age-equivalent magmatic and detrital zircons present in the exposed granitoids and modern river sediments, respectively (SI Appendix, SI Text and Fig. S2). Therefore, the detrital zircon data demonstrate that the Singhbhum cover sequence was sourced locally from variable contributions of the basement granitoids.

The detrital zircon ages together with field observations provide tight constraints on the depositional age of the Singhbhum cover sequence. The youngest detrital zircon age populations in each outlier are characterized by a continuum of concordant $(100 \%)$ to near-concordant (98 to $102 \%$ ) ages between $3.2 \mathrm{Ga}$ and $3.0 \mathrm{Ga}$ (Fig. $1 B$ and SI Appendix, Fig. S1 and SI Text). Such smearing of zircon ages along the concordia curve is typical of ancient Pb-loss. Alpha dose calculations show that detrital zircons younger than $\sim 3.07$ Ga received higher alpha dosages and hence would be more susceptible to $\mathrm{Pb}$-loss, which reduces the confidence in their ages (SI Appendix, SI Text and Fig. S2). Therefore, we propose a conservative maximum depositional age of $\sim 3.08$ Ga for the entire Singhbhum cover sequence. The minimum depositional age of this cover sequence is constrained by the timing of orogenesis in the Rengali Province, which affected the outliers exposed along the southern margin of the craton at $\sim 2.94 \mathrm{Ga}$ (34) (SI Appendix, SI Text). This minimum age is consistent with the intrusion of $\sim 2.8-\mathrm{Ga}$ granitoids into several outliers of the cover sequence throughout the craton $(28,30)$. Thus, the terrestrial to shallow-marine depositional environments, quartz-rich composition, and detrital zircon provenance of the Singhbhum cover sequence document the subaerial erosion of emersed felsic crust of the Singhbhum Craton between $\sim 3.08 \mathrm{Ga}$ and $2.94 \mathrm{Ga}$. This depositional window is consistent with the inferred age $(\sim 3.29$ to $3.08 \mathrm{Ga})$ of the Keonjhar paleosol, which locally underlies the Singhbhum cover sequence (30).

\section{Crustal Thickening Prior to Continental Emersion}

To evaluate the mechanisms behind this early emersion of the Singhbhum Craton, we examine the magmatic evolution of the cratonic crust prior to emersion, which is best documented in the craton's granitoid rock record. The granitoids show a transition from dominantly sodic (Na) TTG magmatism at $\sim 3.53$ to $3.35 \mathrm{Ga}$ to more potassic $(\mathrm{K})$ granite magmatism at $\sim 3.1 \mathrm{Ga}$ through an intervening period $(\sim 3.35$ to $3.24 \mathrm{Ga})$ of granite-trondhjemite magmatism (Fig. $2 A$ ). This magmatic evolution documents an increase in $\mathrm{K} / \mathrm{Na}$ ratio and $\mathrm{Si}$ content and a decrease in $\mathrm{Fe}-\mathrm{Mg}$ content of the granitoids over time (SI Appendix, Fig. S3), reflecting the progressive chemical maturation of the Singhbhum cratonic crust. Comparable geochemical trends are a characteristic feature of the late-stage stabilization of Archean cratons globally $(18,19)$.

Furthermore, the TTGs show a depletion in their heavy rare earth element (HREE), Y, Nb, and Ti contents with time (Fig. $2 B$ and SI Appendix, Fig. S3). We define TTGs as rock types that have $\mathrm{SiO}_{2}=63$ to $75 \mathrm{wt} \%, \mathrm{~K}_{2} \mathrm{O} / \mathrm{Na}_{2} \mathrm{O}<0.8$, and obey the characteristic trace-element compositional constraints (e.g., $\mathrm{Sr} / \mathrm{Y}>25$ ) outlined by previous workers (35) (SI Appendix, Methods). Since HREEs and Y preferentially partition into garnet relative to felsic melt (20), the secular depletion of HREEs and $\mathrm{Y}$ in the Singhbhum TTGs suggest an increase in the proportion of garnet in the melt-residue with time, which in turn implies a progressive increase in the pressure of TTG formation $(22,35-37)$ (Fig. 3A). To quantify this pressure change, we
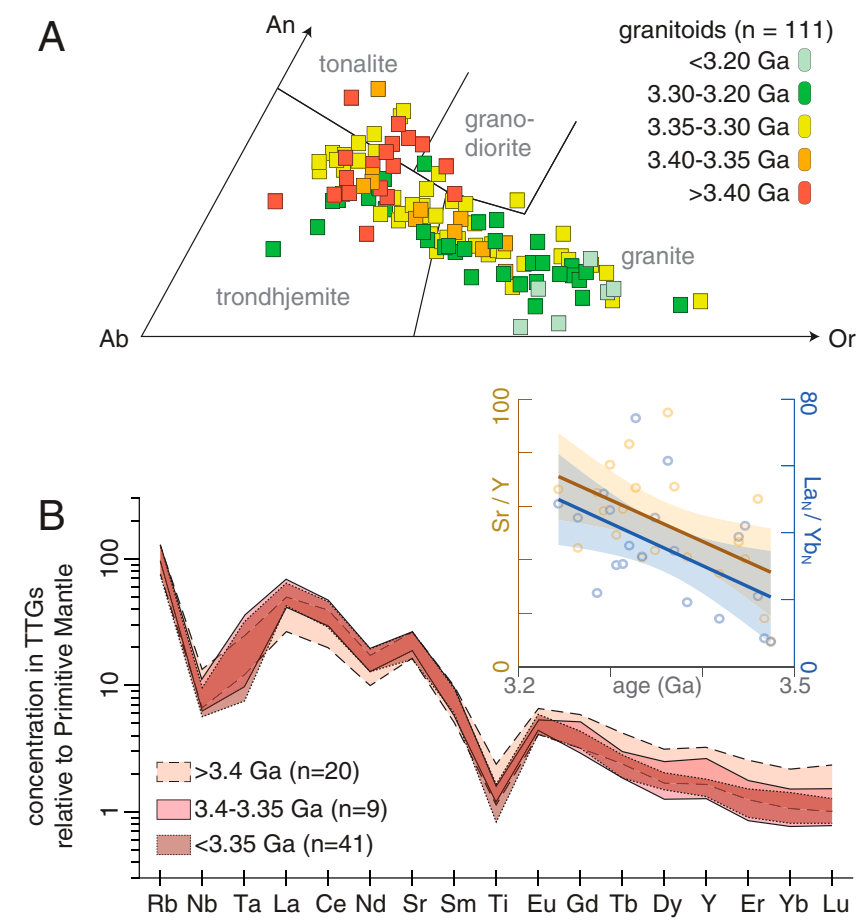

Fig. 2. Evolution of granitoid compositions through time. $(A)$ Normative Anorthite (An)- Albite (Ab)- Orthoclase (Or) plot showing the transition of the Singhbhum Craton's granitoids from tonalite-trondhjemite to trondhjemite-granite to granite with decreasing age. (B) Primitive Mantle (72) normalized plot of the trace-element composition of the Singhhum TTGs, which are grouped by ages. For each age group, the colored region corresponds to the area occupied by trace-element concentrations falling within the interquartile range ( 25 to 75 th percentile) of the dataset (SI Appendix, Fig. S4). Note the gradual depletion of TTGs in HREEs and $Y$ with decreasing age. The Inset in $B$ shows the temporal evolution of $\mathrm{Sr} / \mathrm{Y}$ and $\mathrm{La}_{N} / \mathrm{Yb}_{\mathrm{N}}$ of the TTGs ( $N=$ normalized to chondrite, ref. 72 ). The bold lines represent linear fits to the data, while the associated bands represent the $95 \%$ confidence bounds (SI Appendix, Fig. S3). Data are in Dataset S3. Refer to SI Appendix, Methods for details. 
perform petrogenetic modeling to calculate the trace-element composition of TTG-like melts produced via partial melting of hydrated metabasalts at different $P-T$ conditions and compare the trace-element concentrations of these modeled melts with those of the Singhbhum TTGs (SI Appendix, Methods and Dataset S5). We model melting along two geotherms: $750{ }^{\circ} \mathrm{C} /$ $\mathrm{GPa}$ and $1,000{ }^{\circ} \mathrm{C} / \mathrm{GPa}$, which are appropriate for the Archean (22, 37), and consider both enriched (EAT) and depleted (DAT) Archean tholeiitic basalts as source rocks. Traceelement partitioning coefficients and the mineralogy of meltresidues equilibrating with different melt-fractions sourced from EAT and DAT are taken from published literature $(20,22$, 37) (SI Appendix, Methods). The modeled melts show a better compositional match with the Singhbhum TTGs when an EAT, rather than DAT, source composition is used (SI Appendix, Fig. S4). The modeling demonstrates that the temporal change observed in the trace-element compositions of the Singhbhum TTGs can be accounted for by increasing the pressure of TTG formation from $0.9 \mathrm{GPa}$ at $\sim 3.5$ to $3.4 \mathrm{Ga}$ to $\sim 1.2 \mathrm{GPa}$ at $\sim 3.3$ to $3.24 \mathrm{Ga}$ along a geotherm that decreased from $1,000{ }^{\circ} \mathrm{C} / \mathrm{GPa}$ to $750{ }^{\circ} \mathrm{C} / \mathrm{GPa}$ (Fig. $3 B$ and SI Appendix, Fig. S4). These $P-T$ conditions and geotherms are consistent with those predicted at or near the base of a thick, plateau-like crust if the Archean mantle was hotter than today $(22,38)$. This is further corroborated by numerical modeling studies $(21,23)$. At these depths, a thick Archean crust was likely comprised of (garnet-)amphibolites that would have melted to produce TTGs in response to thermal perturbations in the underlying convecting mantle (22, 38). Thus, we infer that the generation of the Singhbhum TTGs took place within a plateau-like setting (Fig. $3 A$ ) above a zone of rising mantle. This tectonic setting is consistent with the Singhbhum Craton's tectono-metamorphic character, including its dome-and-keel architecture $(28,29,32)$. In this scenario, the pressures calculated from our petrogenetic modeling provide a minimum estimate of crustal thickness (Fig. 3A). Thus, an increase in the pressure of TTG formation from $\sim 0.9 \mathrm{GPa}$ at $\sim 3.5 \mathrm{Ga}$ to $\sim 1.2 \mathrm{GPa}$ at $3.24 \mathrm{Ga}$ (Fig. $3 B$ ) corresponds to an increase in the crustal thickness of the Singhbhum Craton from $\sim 32$ to $\sim 45 \mathrm{~km}$, assuming the bulk density of the crust decreased from $\sim 2,980 \mathrm{~kg} / \mathrm{m}^{3}$ at $\sim 3.5 \mathrm{Ga}$ to $\sim 2,870 \mathrm{~kg} / \mathrm{m}^{3}$ at $\sim 3.2 \mathrm{Ga}$ ("Elevation Calculation" in SI Appendix, Methods) in response to the progressive increase in $\mathrm{Si}$ and decrease in Fe-Mg content of the crust (SI Appendix, Fig. S3).

Alternatively, crustal thicknesses can be estimated from the $\mathrm{La}_{\mathrm{N}} / \mathrm{Yb}_{\mathrm{N}}$ ratio of granitoids, which varies systematically with the Moho depth in modern magmatic arcs $(39,40)$. $\mathrm{La}_{\mathrm{N}} / \mathrm{Yb}_{\mathrm{N}}$ is higher in granitoids that form near the Moho of a thick arc crust where garnet-rich melt-residues or cumulates are stable, whereas it is lower in granitoids that form near the Moho of a thin arc crust where garnet-rich melt-residues or cumulates are less abundant (39). Although calibrated against modern arcs, this method has produced meaningful results for Archean rocks (40). The $\mathrm{La}_{\mathrm{N}} / \mathrm{Yb}_{\mathrm{N}}$ of Singhbhum TTGs imply an increase in Moho depth (i.e., crustal thickness) from $\sim 35 \mathrm{~km}$ at $\sim 3.5 \mathrm{Ga}$ to $\sim 50 \mathrm{~km}$ at $\sim 3.24 \mathrm{Ga}$ (Fig. 3C; SI Appendix, Methods and Dataset S3), which is comparable to the results of our petrogenetic modeling. Thus, both methods show that the Singhbhum cratonic crust thickened by 13 to $15 \mathrm{~km}$ between $\sim 3.5 \mathrm{Ga}$ and 3.24 Ga, which agrees well with the global evolution of Archean continental crust thickness (40, 41).

A
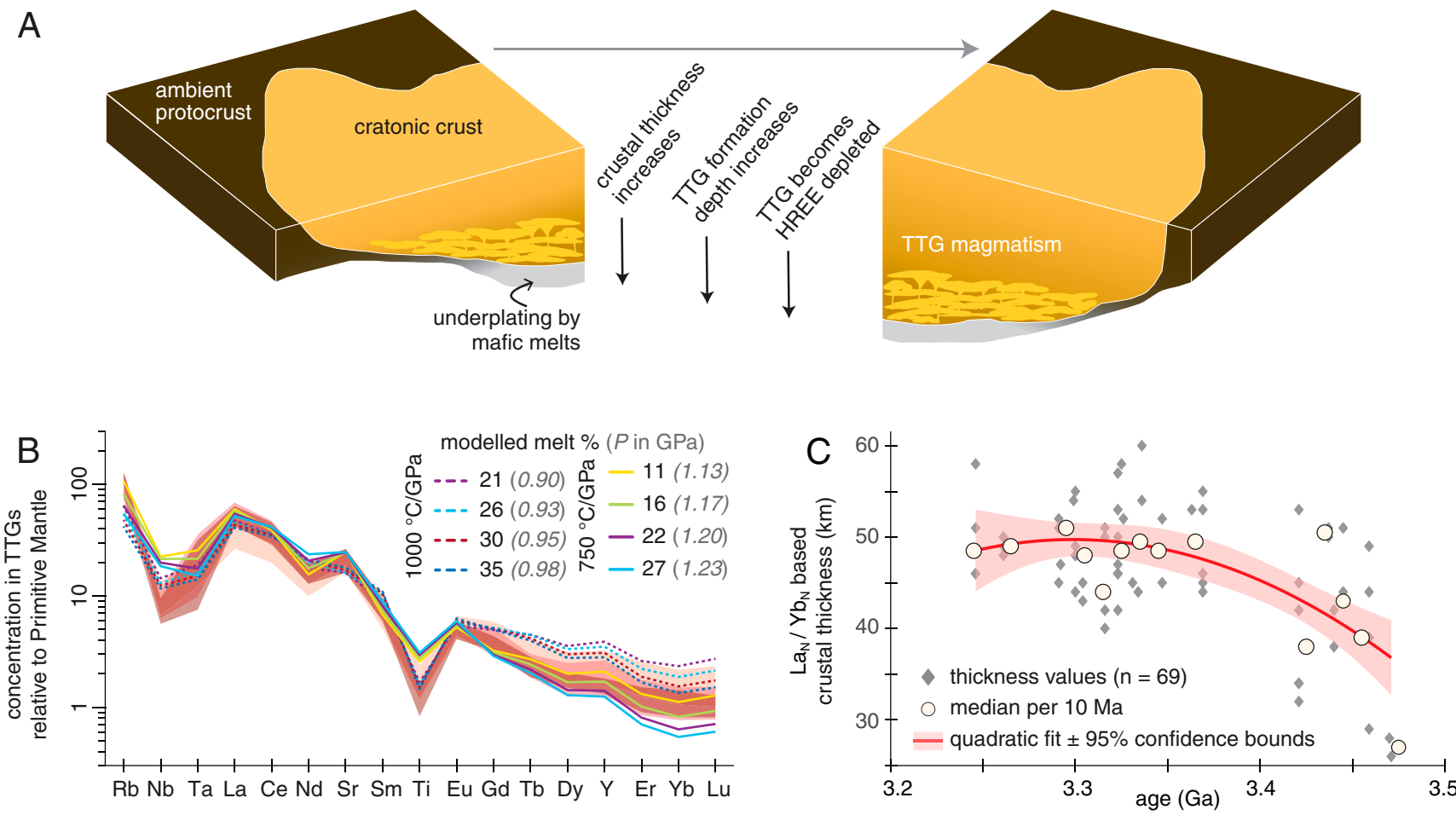

Fig. 3. Evolution of cratonic crustal thickness through time. (A) Schematic diagram showing the correlation between changing TTG composition, depth of TTG formation, and crustal thickness. (B) Primitive Mantle (72) normalized plot of the trace-element composition of the Singhhum TTGs as shown in Fig. 2B. These TTG compositions are compared with those of the modeled, TTG-like melt-fractions forming along two different geotherms from an EAT source rock (SI Appendix, Fig. S4; refer to Dataset S5 for modeled melt compositions). The results show an increase in the pressure and depth of TTG formation with decreasing age $\left(A\right.$ and $B$ ). (C) Estimates of crustal thickness obtained from the La $\mathrm{N}_{\mathrm{N}} / \mathrm{Yb}_{\mathrm{N}} \mathrm{ratios}$ of the Singhbhum TTGs. The solid red line represents a quadratic fit to the individual values (band represents the $95 \%$ confidence bounds). Statistical significance of the fit is confirmed by the $P$ values $(<0.05)$ of the coefficient terms that falsifies the null hypothesis. Median thickness values calculated for each 10 -million-year bin are also shown. Refer to SI Appendix, Methods for details. 
Estimating the crustal thickness of the Singhbhum Craton after $\sim 3.2 \mathrm{Ga}$ is impeded by the absence of TTGs. Only K-granites formed between $\sim 3.2 \mathrm{Ga}$ and $\sim 3.1 \mathrm{Ga}$, which are not suitable for constraining crustal thicknesses as they are derived from variable proportions of older TTGs, metasedimentary rocks, and mafic rocks, such that their compositions are strongly influenced by source-rock compositions besides the $P-T$ conditions of melting $(22,35,42)$. In general, the chemistry of Archean K-granites is consistent with formation at low pressures $(<1 \mathrm{GPa}, \leq 35 \mathrm{~km})$ within a thick felsic crust $(35,42)$. We infer that K-granites of the Singhbhum Craton formed under similar conditions based on their compositional similarity to other Archean K-granites (SI Appendix, Fig. S5). This inference is consistent with the crustal thicknesses estimated from TTGs, which suggest the Singhbhum cratonic crust was $>45 \mathrm{~km}$-thick when the K-granites formed.

\section{Isostatic Rise of Magmatically Thickened Crust}

Linking the magmatic and sedimentary records of the Singhbhum Craton provides critical insight into the interplay between crustal evolution and the onset of continental emersion on early Earth. The granitoids of the Singhbhum Craton document progressive thickening and chemical maturation of the crust between $\sim 3.5 \mathrm{Ga}$ and $\sim 3.24 \mathrm{Ga}$ during the emplacement of large volumes of isotopically juvenile TTGs $\left(\varepsilon \mathrm{Hf}_{(\mathrm{i})}>0 ; S I\right.$ Appendix, Fig. S2). The transition to K-granite magmatism after $\sim 3.2$ Ga reflects an important shift in melt source that is consistent with the establishment of a thick, felsic continental crust before the craton's emersion. Notably, the tectonothermal event(s) accompanying granitoid magmatism in the Singhbhum Craton are characterized by the formation of dome-and-keel structures and the absence of a regional linear tectonic fabric $(28,29,32)$, which suggests that vertical tectonics dominated the formation of the craton. This is also consistent with our petrogenetic modeling, which suggests that the Singhbhum TTGs formed at the deeper levels of a gradually thickening crustal plateau above a zone of mantle upwelling $(21-23,38)$. Therefore, we suggest that the thickening of the Singhbhum cratonic crust was controlled by the emplacement of voluminous TTG magmas between $\sim 3.5 \mathrm{Ga}$ and $\sim 3.2 \mathrm{Ga}$ rather than tectonic thickening related to horizontal compressional tectonics.

The link between the thickening of the Singhbhum cratonic crust and its emersion is further supported by simple isostatic calculations. We compute the craton's elevation $(H)$ as a function of time between $3.5 \mathrm{Ga}$ and $3.1 \mathrm{Ga}$ (Fig. 4; SI Appendix, Methods and Figs. S6 and S7). Notably, we calculate $H$ from the seafloor to make the results independent of Archean sea level, which remains poorly constrained $(8,43,44)$. The value of $H$ at a given time will depend on the thickness and density of the cratonic crust, cratonic lithospheric mantle (CLM), and the ambient submarine, mafic protocrust (SI Appendix, Methods). The evolution of the cratonic crustal thickness and density between $3.5 \mathrm{Ga}$ and $3.1 \mathrm{Ga}$ is approximated from our thickness calculations and the compositional evolution of the crust through time (SI Appendix, Fig. S6). We allow the CLM thickness to increase in time at the length scales of conductive cooling and vary its density $\left(\rho_{C L M}\right)$ such that it remains 0 to 50 $\mathrm{kg} / \mathrm{m}^{3}$ less than the asthenospheric density $\left(\rho_{A M}\right)$ (i.e., $\Delta \rho_{C L M}=$ $\rho_{A M^{-}} \rho_{C L M}=0$ to $50 \mathrm{~kg} / \mathrm{m}^{3}$; SI Appendix, Fig. S6). The density of the ambient submarine mafic protocrust is taken to be 3,000 $\mathrm{kg} / \mathrm{m}^{3}$, and its thickness is varied between $20 \mathrm{~km}$ and $30 \mathrm{~km}$ (45). Our calculations predict that depending on the thickness of the ambient submarine protocrust, the Singhbhum Craton's $H$ would have increased from $\sim 0.8-1.8 \mathrm{~km}$ at $\sim 3.5 \mathrm{Ga}$ to $\sim 3.6-4.6 \mathrm{~km}$ by $3.3 \mathrm{Ga}$ and ultimately to $\sim 4.5-5.5 \mathrm{~km}$ by $3.1 \mathrm{Ga}$ for a $\Delta \rho_{\text {CLM }}$ of $25 \mathrm{~kg} / \mathrm{m}^{3}$ (Fig. 4 and SI Appendix, Fig. S7). This implies a net increase $(\Delta H)$ of $\sim 3.7 \mathrm{~km}$ in the craton's $H$

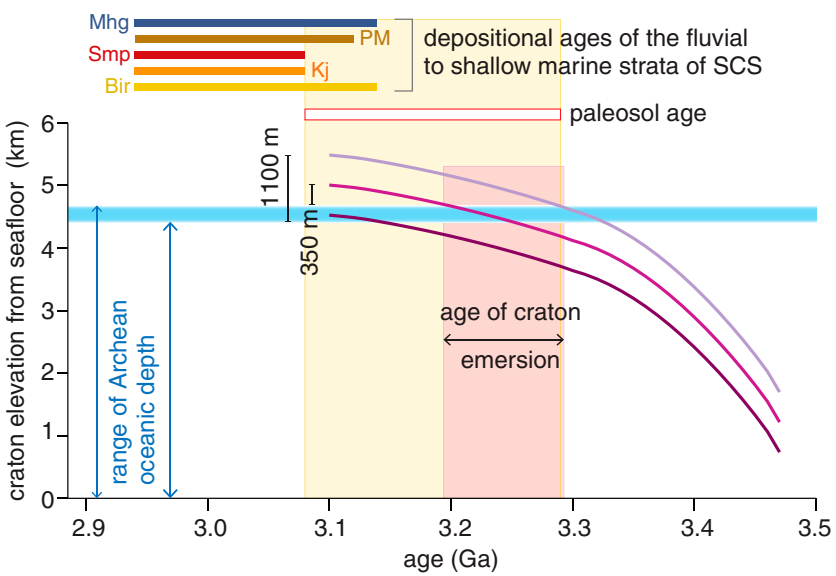

sedimentalogical constraint on the timing of emersion

magmatic-isostatic constraint on the timing of emersion

Fig. 4. Elevation $(H)$ of the Singhbhum Craton from the seafloor as a function of time. Plot showing $H$ versus age curves calculated for three different thicknesses of the ambient submarine (mafic) protocrust. The thickness and density of the cratonic crust are varied with time for each calculation (SI Appendix, Fig. S6). The values of the cratonic crustal thickness at different time instants are approximated from the thickness estimates made in this study. The thickness of the CLM is assumed to increase in time at $40 \%$ of the length scale of conductive cooling (SI Appendix, Fig. S6). The density contrast between the CLM and asthenosphere is taken to be $25 \mathrm{~kg} / \mathrm{m}^{3}$ (variations in $H$ due to variations in CLM density and growth rate are shown in SI Appendix, Fig. S7). The blue band shows the possible range of Archean ocean depth at $\sim 3.2$ to $3.0 \mathrm{Ga}$ (44). The pink band marks the age range of emersion predicted by isostatic modeling, while the yellow band encompasses the time period of emersion constrained by the age of the Singhbhum Cover Sequences (SCS) and Keonjhar paleosol. Horizontal colored bars at the top of the diagram mark the formation ages of the Keonjhar paleosol $(3.29$ to $3.08 \mathrm{Ga}$ ) and individual outliers of the cover sequence (Fig. 1B). Both isostatic modeling and geological constraints predict emersion of the Singhhum craton before $3.1 \mathrm{Ga}$. The $H$ curves corresponding to the $20-\mathrm{km}$ and $25-\mathrm{km}$-thick ambient protocrust predict that the craton's subaerial relief at $\sim 3.1 \mathrm{Ga}$ would have varied between 350 to 1,100 m. Refer to SI Appendix, Methods for details.

between $3.5 \mathrm{Ga}$ and $3.1 \mathrm{Ga}$ (Fig. 4), which is the sum effect of the crustal thickening and maturation (and CLM growth) occurring during that time. Estimating the timing of emersion of the Singhbhum Craton via isostatic modeling requires information about Archean sea level. Constraining Archean sea level is challenging as it depends on the volume of Archean continental crust and oceans, which are poorly known. Nevertheless, a recent study (44) suggests that for more voluminous Archean oceans, the sea level at $\sim 3.2$ to $3.0 \mathrm{Ga}$ was $730 \mathrm{~m}$ to $1,000 \mathrm{~m}$ higher than the present-day sea level depending on the continental volume (SI Appendix, Methods). These sea-level estimates correspond to ocean depths of $4.4 \mathrm{~km}$ to $4.7 \mathrm{~km}$ (compared to the average present-day ocean depth of $3.7 \mathrm{~km}$ ) (46). For this ocean-depth range, the Singhbhum Craton would have emerged above sea level between $3.29 \mathrm{Ga}$ and $3.19 \mathrm{Ga}$ if the ambient submarine protocrust was 20 to $25 \mathrm{~km}$ thick, and its subaerial relief would have varied between 350 and 1,100 m at $\sim 3.1$ Ga (Fig. 4 and SI Appendix, Fig. S7). For a 30-km-thick ambient submarine protocrust, the Singhbhum Craton would have become subaerial by $3.1 \mathrm{Ga}$ if the ocean depth was $4.4 \mathrm{~km}$ (with a subaerial relief of $140 \mathrm{~m}$; SI Appendix, Fig. S7, A3), but it would have remained submerged $(\sim 130 \mathrm{~m}$ below sea level; $S I$ Appendix, Fig. S7, A3) if the ocean depth was $4.7 \mathrm{~km}$ (Fig. 4 and SI Appendix, Fig. S7). The latter situation is inconsistent with the formation of the terrestrial strata of the Singhbhum cover sequence and the Keonjhar paleosol between $3.29 \mathrm{Ga}$ 


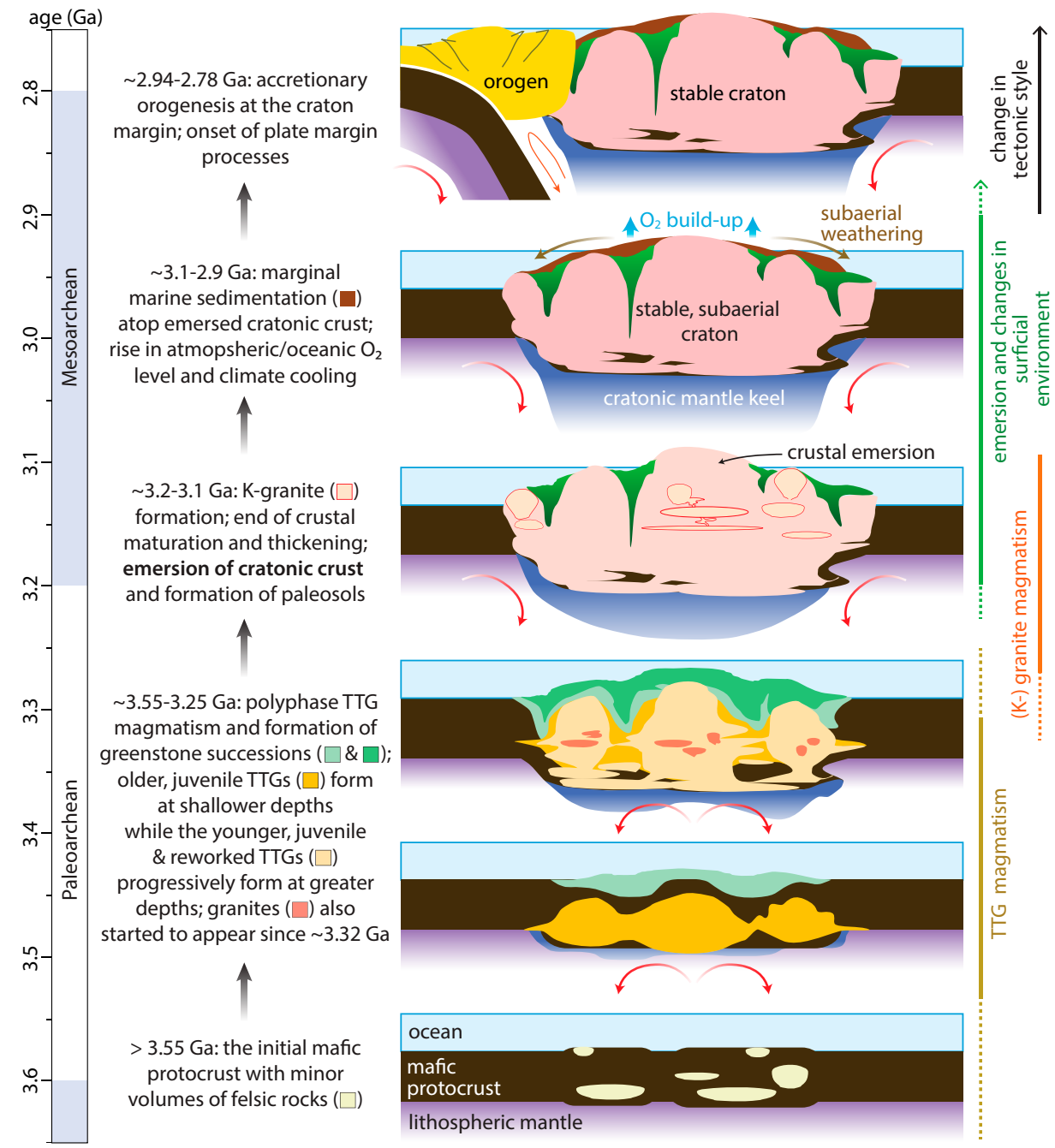

Fig. 5. An illustration of Paleo-Mesoarchean crustal evolution leading to the formation of a subaerial craton. The timeline is based on the evolution of the Singhbhum Craton but is also comparable to that of other cratons. The diagram shows the initiation of craton formation from a mafic dominated protocrust above a zone of mantle upwelling. The cratonic crust progressively thickens and becomes silica rich through the generation of TTGs via partial melting at the lower levels of the developing crustal plateau. The final phase of felsic magmatism comprises K-granites, which form via shallow melting of thickened felsic crust and mark the stabilization of the craton. Prolonged mantle upwelling and melting over a period of $>250$ Ma, as suggested by juvenile TTG magmatism and concomitant greenstone belt volcanism (see Ancestry of the Singhbhum Craton), led to the formation of the melt-depleted CLM simultaneously with the cratonic crust. The thickened and buoyant craton emerges above sea level, which is followed by atmospheric-oceanic oxygenation, cooling of the climate, and a transition to a horizontal, plate tectonic-like geodynamic regime.

and $\sim 3.08 \mathrm{Ga}$, implying that the ocean was $<4.7 \mathrm{~km}$-deep at $\sim 3.1 \mathrm{Ga}$ and/or the ambient submarine protocrust was $<30$ km-thick. Our parametric analyses investigating the sensitivity of $H$ values to variations in ambient submarine protocrustal thicknesses, CLM growth rate, and CLM density show that emersion of the Singhbhum Craton by $3.1 \mathrm{Ga}$ is the most favorable outcome (SI Appendix, Fig. S7). This agrees well with the timing of the development of the Keonjhar paleosol and the depositional age of the Singhbhum cover sequence (Fig. 4).

In addition to the Singhbhum Craton, deposition of Mesoarchean terrestrial to shallow-marine sedimentary strata in the Pilbara, Yilgarn, Slave, Dharwar, and Kaapvaal cratons $(16,17)$ also document the emersion of other cratons by $\sim 3 \mathrm{Ga}$. Among them, the 2.99 - to 2.87-Ga Pongola Supergroup of the (eastern) Kaapvaal Craton and the underlying 2.99 Ga Nsuze paleosol provide a well-preserved record of subaerial weathering and marginal marine sedimentation atop a stable cratonic basement (47-49). The basement of the (eastern) Kaapvaal Craton records voluminous TTG magmatism and formation of greenstone belts from $\sim 3.7 \mathrm{Ga}$ to $3.2 \mathrm{Ga}$ followed by a pulse of K-granite magmatism at $\sim 3.1 \mathrm{Ga}(50)$. This was followed by the formation of the Nsuze paleosol and the deposition of the Pongola Supergroup (48), implying that the craton became subaerial by $\sim 3.1$ to $3.0 \mathrm{Ga}$. This is further corroborated by largescale subaerial volcanism within the craton at $\sim 2.94$ to $2.7 \mathrm{Ga}$ (5). Although the tectonic setting of the (eastern) Kaapvaal Craton is debated $(50,51)$, crustal emersion soon after prolonged granitoid magmatism and associated crustal maturation suggests a causal relationship in which magmatism played a key role in crustal thickening and emersion of the craton, analogous to the inferred evolution of the Singhbhum Craton. The postemersion history of these two cratons are also similar, perhaps most notably in the formation of the $\sim 2.94-$ to $2.78-\mathrm{Ga}$ Rengali Province along the southern margin of the Singhbhum Craton (34) and the Pietersburg block and Limpopo mobile belt along the northern margin of the (eastern) Kaapvaal Craton from $\sim 3.0$ to $2.65 \mathrm{Ga}(50)$. These orogenic belts likely represent the earliest evidence of intense compressional deformation driven 
by horizontal, plate-tectonic processes. However, these events largely postdate crustal thickening, maturation, and emersion of the respective cratonic cores, indicating that plate-tectonic processes were not essential to the emersion of these cratons.

Thus, we suggest that the emersion of Earth's cratons initiated at $\sim 3.3$ to $3.0 \mathrm{Ga}$ due to crustal thickening and maturation caused by voluminous granitoid plutonism within non-plate tectonic settings (Fig. 5). This time estimate significantly precedes the commonly inferred estimate of $2.5 \mathrm{Ga}$ for large-scale continental emersion $(1,4,5,7)$. However, we acknowledge that the areal extent of emersed continental crust likely increased further between $\sim 3.0 \mathrm{Ga}$ and $\sim 2.5 \mathrm{Ga}$ as the mantle cooled from its thermal maximum (45). This progressive cooling would have strengthened the lithosphere and helped establish a global mobile-lid (plate) tectonic regime, which would have facilitated additional thickening of the crust via compressional tectonics $(1,6,10,11,13,18)$. Therefore, we suggest that continental emersion proceeded progressively after being established at the Paleoarchean-Mesoarchean boundary.

\section{Implications of Early Continental Emersion}

The early appearance of subaerial felsic cratons likely caused important changes in Earth's early surficial environments. Intense subaerial weathering and runoff would have supplied nutrients (e.g., phosphorus) to the oceans that were necessary for the proliferation of early life (1). Furthermore, continental emersion would have led to the development of shallow-marine environments, similar to modern continental shelves. Accelerated growth of $\mathrm{O}_{2}$-producing organisms in these environments would have caused a rise in oceanic and atmospheric $\mathrm{O}_{2}$ levels (52). A rise in free $\mathrm{O}_{2}$ would have been further promoted by the weathering of predominantly felsic rocks, which contain lower concentrations of reductants relative to mafic rocks, thereby reducing the loss of free $\mathrm{O}_{2}$ to chemical reactions (53, 54) (Fig. 5). This link between continental emersion and oxygenation is supported by the evidence of oxidative weathering preserved in the $\geq 3$-Ga-old Nsuze (refer to ref. 49 for an alternate view) and Keonjhar paleosols of the Kaapvaal and Singhbhum cratons, respectively $(30,55)$, and the early $(>2.8 \mathrm{Ga})$ record of $\mathrm{O}_{2}$ whiffs $(56,57)$. Additionally, initiation of intense silicate weathering at the craton scale would have promoted a drawn down of atmospheric $\mathrm{CO}_{2}$, leading to cooling and icehouse events. These cooling events are likely recorded by the appearance of glacial diamictites in the Mesoarchean, such as those deposited at $\sim 2.9 \mathrm{Ga}$ in the basins of Pongola Supergroup and West Rand Group of the Kaapvaal Craton $(48,50)$. With the increasing spatial extent of emersed continental

1. I. N. Bindeman et al., Rapid emergence of subaerial landmasses and onset of a modern hydrologic cycle 2.5 billion years ago. Nature 557, 545-548 (2018)

2. C.-T. A. Lee et al., Deep mantle roots and continental emergence: Implications for whole-Earth elemental cycling, long-term climate, and the Cambrian explosion. Int Geol. Rev. 60, 431-448 (2018).

3. N. Arndt, Why was flood volcanism on submerged continental platforms so common in the Precambrian? Precambrian Res. 97, 155-164 (1999).

4. J. W. Valley et al., 4.4 billion years of crustal maturation: Oxygen isotope ratios of magmatic zircon. Contrib. Mineral. Petrol. 150, 561-580 (2005)

5. L. R. Kump, M. E. Barley, Increased subaerial volcanism and the rise of atmospheric oxygen 2.5 billion years ago. Nature 448, 1033-1036 (2007).

6. N. Flament, N. Coltice, P. F. Rey, A case for late-Archaean continental emergence from thermal evolution models and hypsometry. Earth Planet. Sci. Lett. 275, 326-336 (2008).

7. M.-L. Pons et al., A Zn isotope perspective on the rise of continents. Geobiology 11, 201-214 (2013)

8. J. Korenaga, N. J. Planavsky, D. A. D. Evans, Global water cycle and the coevolution of the Earth's interior and surface environment. Philos. Trans.- Royal Soc., Math. Phys. Eng. Sci. 375, 20150393 (2017).

9. N. D. Greber, N. Dauphas, The chemistry of fine-grained terrigenous sediments reveals a chemically evolved Paleoarchean emerged crust. Geochim. Cosmochim. Acta 255, 247-264 (2019).

10. P. A. Cawood, C. J. Hawkesworth, Continental crustal volume, thickness and area and their geodynamic implications. Gondwana Res. 66, 116-125 (2019). landmasses during the Neoarchean, these changes in surficial environments likely became more prominent, permanent, and widespread $(1,7)$.

\section{Materials and Methods}

Zircon and Granitoid Data. The detrital zircon U-Pb(-Hf) data of the Mahagiri, Pallahara-Mankaharchua, Keonjhar, and Birtola outliers of the Singhbhum cover sequence were taken from the literature (Datasets S1 and S2). For the Simlipal outlier, we obtained new detrital zircon U-Pb-Hf data (Datasets S1 and S2) using laser ablation split stream inductively coupled plasma mass spectrometry at the Isotopia Facility, Monash University. The analytical details are described in SI Appendix, Methods. The whole-rock geochemical data and zircon Lu-Hf data of the Singhbhum granitoids were also taken from the literature (Dataset S3). Refer to SI Appendix, Methods for details.

Petrogenetic Modeling. We modeled the trace-element concentrations of melt-fractions ( 0.05 to 0.35 ) produced via partial melting of metabasalts using published phase equilibria results and partitioning coefficients. Modeling details are described in SI Appendix, Methods, and the input parameters and the modeled melt compositions are given in Dataset S5. While comparing with the Singhbhum TTGs, we only considered modeled melt-fractions with $\mathrm{K} / \mathrm{Na}<1$ and $\mathrm{SiO}_{2}>63 \mathrm{wt} \%$ as TTG-like melts. The thickness of the Singhbhum cratonic crust between $3.5 \mathrm{Ga}$ and $3.1 \mathrm{Ga}$ was estimated from the results of petrogenetic modeling and the TTG La $/ \mathrm{Yb}_{N}$ ratios (SI Appendix, Methods and Dataset S3).

Elevation Calculation. We calculated the craton's elevation (from the seafloor) considering the isostatic compensation to occur at the base of the CLM. The craton's elevation changed during $\sim 3.5$ to $3.1 \mathrm{Ga}$ due to changing cratonic crustal thickness, density, and CLM thickness. We computed these parameters as a function of time $(\mathrm{t})$ using the following relations: crustal thickness $(\mathrm{km})=$ $-4.995 \times 10^{-4} t^{2}+3.306 t-5424$ ( $t$ in Ma; until $3.3 \mathrm{Ga}$ and then kept constant); crustal density $\left(\mathrm{kg} / \mathrm{m}^{3}\right)=596.184 t^{2}-3565.58 t+8173.967$ ( $t$ in Ga); and CLM thickness $=\sqrt{4 k t}$ and $0.4 \times \sqrt{4 k t}$, where $k=10^{-6} \mathrm{~m}^{2} / \mathrm{s}$ is thermal diffusivity. Full details of the modeling, including a complete description of the parameter values used, are given in SI Appendix, Methods.

Programs Used. IsoplotR (https://www.ucl.ac.uk/ ucfbpve/isoplotr/home/index. html) was used for analyzing the detrital zircon ages. All other statistical analyses and modeling were done in MATLAB.

Data Availability. All data are given in the article and/or supporting information. This includes the previously published data that were used for this work $(30,31,58-71)$. MATLAB codes and input files used in this study are available from GitHub (https://github.com/priyadarshi-geo/Continental-Emersion-2021).

ACKNOWLEDGMENTS. We thank the editor and three anonymous reviewers for their thorough and constructive reviews. We thank Rachelle Pierson (Monash University) and Graham Hutchinson (University of Melbourne) for assisting in sample processing and CL imaging of detrital zircons. Discussions with Pulak Sengupta, Jean-François Moyen, Oscar Laurent, and Fabio Capitanio are gratefully acknowledged.

11. K. Chen et al., How mafic was the Archean upper continental crust? Insights from Cu and Ag in ancient glacial diamictites. Geochim. Cosmochim. Acta 278, 16-29 (2020)

12. B. W. Johnson, B. A. Wing, Limited Archaean continental emergence reflected in an early Archaean 18 O-enriched ocean. Nat. Geosci. 13, 243-248 (2020)

13. J. R. Reimink, J. H. F. L. Davies, A. lelpi, Global zircon analysis records a gradual rise of continental crust throughout the Neoarchean. Earth Planet. Sci. Lett. 554, 116654 (2021).

14. R. Buick et al., Record of emergent continental crust $\sim 3.5$ billion years ago in the Pitbara craton of Australia. Nature 375, 574-577 (1995).

15. R. Rye, H. D. Holland, Paleosols and the evolution of atmospheric oxygen: A critical review. Am. J. Sci. 298, 621-672 (1998).

16. P. G. Eriksson et al., Secular changes in sedimentation systems and sequence stratig raphy. Gondwana Res. 24, 468-489 (2013).

17. D. G. F. Long, Archean fluvial deposits: A review. Earth Sci. Rev. 188, 148-175 (2019).

18. P. A. Cawood et al., Geological archive of the onset of plate tectonics. Philos. Trans. Royal Soc., Math. Phys. Eng. Sci. 376, 20170405 (2018)

19. J.-F. Moyen, O. Laurent, Archaean tectonic systems: A view from igneous rocks. Lithos 302-303, 99-125 (2018).

20. J. H. Bédard, A catalytic delamination-driven model for coupled genesis of Archaean crust and sub-continental lithospheric mantle. Geochim. Cosmochim. Acta 70, 1188-1214 (2006).

21. E. Sizova, T. Gerya, K. Stüwe, M. Brown, Generation of felsic crust in the Archean: A geodynamic modeling perspective. Precambrian Res. 271, 198-224 (2015) 
22. T. E. Johnson, M. Brown, N. J. Gardiner, C. L. Kirkland, R. H. Smithies, Earth's first stable continents did not form by subduction. Nature 543, 239-242 (2017).

23. A. B. Rozel, G. J. Golabek, C. Jain, P. J. Tackley, T. Gerya, Continental crust formation on early Earth controlled by intrusive magmatism. Nature 545, 332-335 (2017).

24. R. M. Holder, D. R. Viete, M. Brown, T. E. Johnson, Metamorphism and the evolution of plate tectonics. Nature 572, 378-381 (2019).

25. M. Tang, C.-T. A. Lee, R. L. Rudnick, K. C. Condie, Rapid mantle convection drove massive crustal thickening in the late Archean. Geochim. Cosmochim. Acta 278, 6-15 (2020).

26. R. Mazumder et al., Mesoarchaean-Palaeoproterozoic stratigraphic record of the Singhbhum crustal province, eastern India: A synthesis. Geol. Soc. Lond. Spec. Publ. 365, 31-49 (2012).

27. R. Mazumder, T. Chaudhuri, S. Biswas, Palaeoarchaean sedimentation and magmatic processes in the eastern Iron Ore Group, eastern India: A commentary. Geol. J. 54, 3078-3087 (2019).

28. T. Chaudhuri, A review of Hadean to Neoarchean crust generation in the Singhbhum Craton, India and possible connection with Pilbara Craton, Australia: The geochronological perspective. Earth Sci. Rev. 202, 103085 (2020).

29. H. K. H. Olierook et al., Evolution of the Singhbhum Craton and supracrustal provinces from age, isotopic and chemical constraints. Earth Sci. Rev. 193, 237-259 (2019).

30. J. Mukhopadhyay et al., Oxygenation of the Archean atmosphere: New paleosol constraints from eastern India. Geology 42, 923-926 (2014).

31. S. Dey et al., "Early crustal evolution as recorded in the granitoids of the Singhbhum and Western Dharwar Cratons" in Earth's Oldest Rocks, M. J. Van Kranendonk, V. C. Bennett, J. E. Hoffmann, Eds. (Elsevier, 2019), pp. 741-792.

32. N. Prabhakar, A. Bhattacharya, Paleoarchean partial convective overturn in the Singhbhum Craton, Eastern India. Precambrian Res. 231, 106-121 (2013).

33. D. Upadhyay, S. Chattopadhyay, E. Kooijman, K. Mezger, J. Berndt, Magmatic and metamorphic history of Paleoarchean tonalite-trondhjemite-granodiorite (TTG) suite from the Singhbhum craton, eastern India. Precambrian Res. 252, 180-190 (2014).

34. S. Bose et al., Zircon and monazite geochronology from the Rengali-Eastern Ghats Province: Implications for the tectonic evolution of the eastern Indian terrane. Precambrian Res. 355, 106080 (2021)

35. J.-F. Moyen, The composite Archaean grey gneisses: Petrological significance, and evidence for a non-unique tectonic setting for Archaean crustal growth. Lithos 123, 21-36 (2011).

36. R. M. Palin, R. W. White, E. C. R. Green, Partial melting of metabasic rocks and the generation of tonalitic-trondhjemitic-granodioritic (TTG) crust in the Archaean Constraints from phase equilibrium modelling. Precambrian Res. 287, 73-90 (2016).

37. J. Kendrick, C. Yakymchuk, Garnet fractionation, progressive melt loss and bulk composition variations in anatectic metabasites: Complications for interpreting the geodynamic significance of TTGs. Geoscience Frontiers 11, 745-763 (2020).

38. R. H. Smithies, D. C. Champion, M. J. Van Kranendonk, Formation of Paleoarchean continental crust through infracrustal melting of enriched basalt. Earth Planet. Sci. Lett. 281, 298-306 (2009)

39. L. Profeta et al., Quantifying crustal thickness over time in magmatic arcs. Sci. Rep. $\mathbf{5}$ 17786(2015).

40. C. Balica et al., A zircon petrochronologic view on granitoids and continental evolution. Earth Planet. Sci. Lett. 531, 116005 (2020).

41. M. Tang, X. Chu, J. Hao, B. Shen, Orogenic quiescence in Earth's middle age. Science 371, 728-731 (2021).

42. R. W. White, R. M. Palin, E. C. R. Green, High-grade metamorphism and partial melting in Archean composite grey gneiss complexes. J. Metamorph. Geol. 35, 181-195 (2017).

43. E. C. Pope, D. K. Bird, M. T. Rosing, Isotope composition and volume of Earth's early oceans. Proc. Natl. Acad. Sci. U.S.A. 109, 4371-4376 (2012).

44. J. C. Rosas, J. Korenaga, Archaean seafloors shallowed with age due to radiogenic heating in the mantle. Nat. Geosci. 14, 51-56 (2021)

45. C. Herzberg, K. Condie, J. Korenaga, Thermal history of the Earth and its petrological expression. Earth Planet. Sci. Lett. 292, 79-88 (2010).

46. B. W. Eakins, G. F. Sharman, Volumes of the World's Oceans from ETOPO1 (NOAA National Geophysical Data Center, 2010).

47. A. H. Wilson, A. Zeh, U-Pb and $\mathrm{Hf}$ isotopes of detrital zircons from the Pongola Supergroup: Constraints on deposition ages, provenance and Archean evolution of the Kaapvaal craton. Precambrian Res. 305, 177-196 (2018).

48. C. Luskin, A. Wilson, D. Gold, A. Hofmann, "The Pongola Supergroup: Mesoarchaean Deposition Following Kaapvaal Craton Stabilization" in The Archaean Geology of the Kaapvaal Craton, Southern Africa, Regional Geology Reviews, A. Kröner, A. Hofmann, Eds. (Springer International Publishing, 2019), pp. 225-254.

49. A. W. Heard et al., Anoxic continental surface weathering recorded by the $2.95 \mathrm{Ga}$ Denny Dalton Paleosol (Pongola Supergroup, South Africa). Geochim. Cosmochim. Acta 295, 1-23 (2021).

50. A. Kröner, A. Hofmann, Eds., The Archaean Geology of the Kaapvaal Craton, South ern Africa (Springer International Publishing, 2019)

51. M. J. Van Kranendonk et al., Making it thick: A volcanic plateau origin of Palaeoarchean continental lithosphere of the Pilbara and Kaapvaal cratons. Geol. Soc. Lond. Spec. Publ. 389, 83-111 (2015).

52. I. H. Campbell, D. R. Davies, Raising the continental crust. Earth Planet. Sci. Lett. $\mathbf{4 6 0}$ 112-122 (2017)

53. C.-T. A. Lee et al., Two-step rise of atmospheric oxygen linked to the growth of continents. Nat. Geosci. 9, 417-424 (2016).

54. M. A. Smit, K. Mezger, Earth's early $\mathrm{O} 2$ cycle suppressed by primitive continents. Nat Geosci. 10, 788-792 (2017)

55. S. A. Crowe et al., Atmospheric oxygenation three billion years ago. Nature $\mathbf{5 0 1}$ 535-538 (2013)

56. N. J. Planavsky et al., Evidence for oxygenic photosynthesis half a billion years before the Great Oxidation Event. Nat. Geosci. 7, 283-286 (2014).

57. T. W. Lyons, C. T. Reinhard, N. J. Planavsky, The rise of oxygen in Earth's early ocean and atmosphere. Nature 506, 307-315 (2014)

58. S. Bhattacharjee, J.A. Mulder, S. Roy, P. Chowdhury, P.A. Cawood, O. Nebel, Unraveling depositional setting, age and provenance of the Simlipal volcano-sedimentary complex, Singhbhum craton: Evidence for Hadean crust and Mesoarchean marginal marine sedimentation. Precambrian Research, 354, 106038 (2021).

59. S. Bose et al., Neoarchean tectonothermal imprints in the Rengali Province, eastern India and their implication on the growth of Singhbhum Craton: evidence from zircon U-Pb SHRIMP data. Journal of Metamorphic Geology, 34, 743-764 (2016).

60. T. Chakraborty, D. Upadhyay, S. Ranjan, K.L. Pruseth, J.K. Nanda, The geologica evolution of the Gangpur Schist Belt, eastern India: Constraints on the formation of the Greater Indian Landmass in the Proterozoic. J. Metamorph. Geol. 37, 113-151 (2019)

61. S.R. Miller et al., Detrital zircons reveal evidence of Hadean crust in the Singhbhum Craton, India. J. Geol., 126, 541-552 (2018).

62. S. Ranjan, D. Upadhyay, K.L. Pruseth, J.K. Nanda, Detrital zircon evidence for change in geodynamic regime of continental crust formation 3.7-3.6 billion years ago. Earth Planet. Sci. Lett. 538, 116206 (2020)

63. B. Sreenivas et al., A new cache of Eoarchaean detrital zircons from the Singhbhum craton, eastern India and constraints on early Earth geodynamics. Geosci. Front. 10 1359-1370 (2019)

64. S. Dey, S.K. Nayak, A. Mitra, K. Zong, Y. Liu, Mechanism of Paleoarchean Continental Crust Formation as Archived in Granitoids from Northern Part of Singhbhum Craton, Eastern India (The Geological Society of London, London, 2020).

65. S. Dey, A. Topno, Y. Liu, K. Zong, Generation and evolution of Paleoarchaean continental crust in the central part of the Singhbhum craton, eastern India. Precambrian Res., 298, 268-291 (2017).

66. Aniruddha Mitra, S. Dey, K. Zong, Y. Liu, Anirban Mitra, Building the core of a Paleoarchean continent: Evidence from granitoids of Singhbhum Craton, eastern India. Precambrian Res., 335, 105436 (2019).

67. D.R. Nelson, H.N. Bhattacharya, E.R. Thern, W. Altermann, Geochemical and ion microprobe U-Pb zircon constraints on the Archaean evolution of Singhbhum Craton, eastern India. Precambrian Res., 255, 412-432 (2014).

68. O.P. Pandey et al., Genesis of the Singhbhum Craton, eastern India; implications for Archean crust-mantle evolution of the Earth. Chem. Geol., 512, 85-106 (2019).

69. J. Tait et al., Possible juvenile Paleoarchaean TTG magmatism in eastern India and its constraints for the evolution of the Singhbhum craton. Geol. Mag., 148, 340-347 (2011).

70. D. Upadhyay, S. Chattopadhyay, K. Mezger, Formation of PaleoarcheanMesoarchean Na-rich (TTG) and K-rich granitoid crust of the Singhbhum craton, eastern India: Constraints from major and trace element geochemistry and $\mathrm{Sr}-\mathrm{Nd}$-Hf isotope composition. Precambrian Res., 327, 255-272 (2019).

71. T. Chaudhuri, Y. Wan, R. Mazumder, M. Ma, D. Liu, Evidence of Enriched, Hadean Mantle Reservoir from 4.2 to $4.0 \mathrm{Ga}$ zircon xenocrysts from Paleoarchean TTGs of the Singhbhum Craton, Eastern India. Sci. Rep., 8, 7069 (2018).

72. W. F. McDonough, S.-s. Sun, The composition of the Earth. Chem. Geol. 120, 223-253 (1995) 